\title{
Bacterial microflora of seeds of cultivars of tomatoes at treatment with fungicide
}

\author{
Yu. Kolomiyets, \\ Candidate of Biological Sciences \\ I. Grygoriuk, \\ Corresponding Member of the National Academy of Sciences of Ukraine, Doctor of Biological \\ Sciences \\ National Univ \\ ersity of Life and Enviromental Scienses of Ukraine \\ L. Butsenko, Candidate of Biological Sciences \\ Institute of Microbiology and Virology D. K. Zabolotny National Academy of Sciences of \\ Ukraine
}

The purpose. To analyze qualitative changes in structure of microbiota of seeds of cultivars of tomatoes at pre-seeding treatment with fungicide. Methods. In researches they used the treated and not treated seeds of 16 determinant cultivars of tomatoes of Ukrainian selection. Seed analysis of tomatoes was carried out with the use of classical microbiological methods. Antagonistic activity of isolates was determined by method of perpendicular strokes. Results. From the surface of raw seeds bacterial isolates were secreted with different quantitative and qualitative structures of microflora. The seeds of cultivars of tomatoes processed by seed dresser were characterized by presence only of 4 kinds of colonies. On the raw seeds there were revealed 5 isolates with antagonistic activity in as to the testcultures. Conclusions. Microbiothat of seeds of cultivars of tomatoes not processed by fungicide is more various, than that of treated. It is determined that isolates $\mathrm{OB} 1, \mathrm{OB} 2, \mathrm{ChA} 3, \mathrm{KM} 2$ and FL1 from epiphytic microflora of not processed seeds of tomatoes are perspective for restriction of development of causal organisms of bacterial cancer, bacterial mottling and black bacterial spot.

Key words: tomato, seeds, microbiothat, seed dressers, useful microflora.

The surface of plants is inhabited by aboriginal microorganisms and random, which are rapidly eliminated. A significant amount of microbes is deposited on plants and seeds with wind, dust, rain, etc. The species composition and number of microorganisms on the plant surface is regulated by the macroorganism of the plant-nutrient and the environmental conditions. Plants distinguish organic and mineral substances used by microorganisms $[5,13]$.

Seed microflora can have a stimulating and inhibitory effect on seed germination and plant productivity. A significant number of epiphiae can produce vitamins and substances that stimulate the growth, development and formation of a powerful root system of plants [8]. It is shown that quantitative and qualitative composition of microflora, for example, soybean seeds depends on varietal features, weather conditions, phases of growth and development of plants [6].

Saprotrophic microorganisms do not cause an infectious process, form a dynamic equilibrium in the system of "saprotrophus - a pathogen" and increase the resistance of plants to phytopathogenic organisms. Bacterial endo- and epiphytes protect plants from nematodes and harmful insects, increase their resistance to abiotic and biotic factors of the medium [10]. Protective role is also characteristic for weakly aggressive phytopathogenic bacteria, because a weakly aggressive strain causes increased resistance of plants to highly aggressive. Almost the amount of phytopathogenic bacteria on the surface of organs of plants depends on species characteristics, phases of the growing season, climatic conditions, intensity and direction of physiological and biochemical processes [7].

The metabolism of pathogens in structural compartments of seeds, even in small quantities, pays special attention to agricultural production, which ensures the spread of pathogens that cause a decrease in the quality and yield of field crops [12].

The decontamination of seeds of tomatoes is carried out by heat treatment and processing with substances of plant and chemical origin. Under the influence of pollinators, a reduction in the ability of bacteria to biosynthesis of biologically active substances, which can play a significant role in the relationship between epiphytic bacteria and plants [2, 10, 11]. Maintenance and conservation of the 
optimum level of biodiversity associated with plants of microorganisms is the basis of their natural protection against pathogens.

Thus, microorganisms of the leaf surface and seeds, including phytopathogenic, form peculiar associations, the effect on which chemical and biological pesticides studied fragmentarily.

The purpose of the research is to establish deterministic changes in the qualitative composition of microbiota of tomato varieties of seeds for its pre-planting with fungicide.

Research methodology. The object of research was not processed and processed by a seed chemist of 16 determinant tomato varieties of Ukrainian selection. They are listed in the State Register of Plant Varieties, which are suitable for spreading in Ukraine in 2015, which are resistant to major fungal diseases. Specifically, these are the Chaika, Malynovyi dzvin, Flora, Klondaik, Eleonora, Oberih, Atlasnyi, Zoreslav, Hospodar, Kimmeriets, Dama, Lehin, Lyubimy, Talan, Flandriia and Kumach. To investigate the effectiveness of the fungicide action on the microbiote, seeds of tomato plants were treated with a test substance with active substances of $200 \mathrm{~g} / \mathrm{l}$ of carboxin, $200 \mathrm{~g} / \mathrm{l}$ of tiram.

To isolate bacteria, seeds of tomatoes after 15 minutes of washing with running water and sterile water washed in a mortar with $0,5 \mathrm{ml}$ of saline solution, after which a small amount of material was applied to the potato agar surface with dense strokes from one end of the Petri cup to the other. The bacteria were cultured in a thermostat for $24 \mathrm{~h}$ at a temperature of $28^{\circ} \mathrm{C}$. The morphological properties of bacteria were studied by classical methods $[4,14]$.

The antagonistic activity of the isolates was determined by the method of delayed antagonism. For this purpose, a potential antagonist was sown on potato agar with a stroke for diagonal of a Petri dish. After 5 days of cultivation perpendicular to the growth pathway of the bacterial antagonists, the slurry of the test culture cells was subjected to a suspension of $10^{6} \mathrm{cell} / \mathrm{s} / \mathrm{ml}$ according to the standard of turbidity [8]. As a test culture, Clavibacter michiganensis subsp. michiganensis (Smith 1910) Davis et al. 1984 strains P8, P12, P73, P110, P115 and 4999, Pseudomonas syringae pv. tomato (Okabe 1933) Young et al. 1978 strains 4213, Pst2, Psr120 and BB9 (obtained from the Institute of Pesticides and Plant Protection, Serbia), Xanthomonas vesicatoria (Doidge 1920) Vauterin et al. 1995 strain 9098 (from the collection of the Department of Phytopathogenic Bacteria of the Institute of Microbiology and Virology named after D. K. Zabolotny of the National Academy of Sciences of Ukraine). The degree of sensitivity of the test cultures to the influence of the antagonist was estimated by the size of the diameter of the inhibition zone of the growth of the test culture.

Statistical processing of the results was carried out using the package STATISTICA v.6.0.

Research results. Seed treatment is one of the important measures in the system of protection of crops from crops from diseases and pests, which causes significant changes in the composition of microorganisms on the surface of the seed, which can inhibit the growth and development of plants.

The obtained isolates from the surface of seeds of 16 varieties of tomatoes had colonies of various shapes, yellow, white, beige, pink, brown and orange, transparent and translucent, with a matte and glossy surface, even and uneven edges. For each variety of tomatoes, different quantitative and qualitative composition of the microflora of the seed was characteristic. The overwhelming number of isolates from untreated tomato seeds seeds monitor indicates a relatively greater diversity of microbiota.

The largest number of types of isolates we have isolated from the unformulated fungicide of seagull seeds (table 1), from which was isolated: 1 - isolate with grayish-white colonies, 3 - pink and 11, forming colonies painted yellow (from cream to orange). The microbiota of tomato Flora, Hospodar, Kimmeriets, Dama and Flandriia was also noted for a variety of species composition. Of these varieties of tomatoes, 36 isolates of yellow and 12 - grayish-white were isolated. The smallest species composition is defined in the microbiota from the seeds of varieties Klondaik, Lyubimy and Kumach. From the Klondaik variety, 1 isolate with yellow colonies and 2 - beige color were selected. Yellow-pigment colonies based on morphological and cultural properties, we have previously been identified as Pantoea agglomerans.

Chemical dressing of seeds is an integral part of the protective technologies of storage and preparation for sowing, which, however, can cause a disturbance of the dynamic equilibrium between individual groups of microorganisms and stimulate the occurrence of pathological processes in plants during ontogenesis [7]. Under the influence of chemical and biological pesticides, not only the inhibition of the development of pathogens, but also the decrease in the number of microorganisms of beneficial microflora, which limit the spread of pathogens of different virulence and degree of aggressiveness.

Under the conditions of processing of seeds of tomato varieties with fungicide there was a significant decrease in the number and variety of microorganisms (table 1). For the treated toy with active substances, $200 \mathrm{~g} / \mathrm{l}$ of carboxin, $200 \mathrm{~g} / \mathrm{l}$ of tiram of seeds of tomato varieties was characterized by only 
four types of colonies: beige color with even edges of convex shape and with uneven flat, as well as flat and convex grayish-white color with even edges. On the surface of the protuberous seeds there are no bacteria that form the yellow pigment colonies, among which there are representatives of the species Pantoea agglomerans. According to R. I. Gvozdiak [3], on the surface of seeds and plants of bacteria Pantoea agglomerans can be up to $80-90 \%$ of the total bacterial microflora called "bacteria-satellites", which are antagonists to phytopathogens.

1. Bacteriological analysis of seeds of tomato varieties

\begin{tabular}{|c|c|c|c|c|c|}
\hline \multirow[t]{3}{*}{ Kind } & \multicolumn{5}{|c|}{ Number of isolates of bacteria isolated from the seed } \\
\hline & \multicolumn{3}{|c|}{ untreated treated with a trapezoid } & \multicolumn{2}{|c|}{ treated with a trapezoid } \\
\hline & $\begin{array}{l}\text { yellow } \\
\text { pigmented }\end{array}$ & $\begin{array}{l}\text { gray with white } \\
\text { color }\end{array}$ & pink color & beige color & $\begin{array}{l}\text { gray with white } \\
\text { color }\end{array}$ \\
\hline Chaika & 11 & 1 & 3 & 2 & 1 \\
\hline $\begin{array}{l}\text { Malynovyi } \\
\text { dzvin }\end{array}$ & 6 & 2 & 2 & 2 & 2 \\
\hline Flora & 8 & 2 & 3 & 1 & 2 \\
\hline Klondaik & 1 & 1 & 1 & - & 1 \\
\hline Eleanora & 5 & 2 & 3 & 1 & - \\
\hline Oberih & 6 & 2 & - & 1 & 1 \\
\hline Atlasnyi & 5 & 3 & 1 & 2 & 1 \\
\hline Zoreslav & 6 & 2 & - & 2 & 2 \\
\hline Hospodar & 7 & 2 & 2 & 2 & 1 \\
\hline Kimmeriets & 8 & 2 & 2 & 1 & 2 \\
\hline Dama & 6 & 3 & 2 & 1 & - \\
\hline Lehin & 7 & 3 & - & - & 2 \\
\hline Lyubimy & 3 & 1 & 1 & 2 & 1 \\
\hline Talan & 5 & 1 & 1 & - & 1 \\
\hline Flandriia & 7 & 3 & 2 & 1 & 2 \\
\hline Kumach & 2 & 2 & 1 & 1 & 1 \\
\hline $\mathrm{NIR}_{05}$ & 2,88 & 2,29 & 2,88 & 1,27 & 1,27 \\
\hline
\end{tabular}

Resistance to pathogens depends on the presence of microflora of microorganisms with antagonistic properties and the ability to quickly colonize the surface of plants. Particularly important antagonists of phytopathogenic bacteria and fungi in phytoagrants are representatives of the genera Pseudomonas, Bacillus, Trichoderma, Chaetomium, Pantoea and some other microorganisms [1, 3].

For further research among isolated isolates from untreated tomato seeds, we isolated 5 isolates that exhibited antagonistic activity in relation to test cultures. Isolate $\mathrm{CHA} 3$ is isolated from seed of Chaika, isolates OB1 and OB2 - from seeds of Oberih, isolate KM2 - Kimmeriets, isolate FL1 - Flandriia. For the isolate $\mathrm{CHA} 3$, the formation of matte and flat beige colonies with a dark pattern and equal edges was characteristic, OB1 - matte, dark brown color and flat colonies of irregular shape, OB2 - matte, flat colonies of light-beam color with uneven edges, KM2 - shiny, with dark uplifted center of colonies of beige color and uneven edges, FL1 - brilliant and grayish-white with even edges.

Isolate OB2 exhibited high antagonistic activity against the bacterial sputum agent, the diameter of the inhibition of the growth of strains $P$. syringae pv. tomato 4213, Pst2, Psr120 and BB9 were from 74 to 80 $\mathrm{mm}$ (table 2).

\section{Antagonistic activity of isolates isolated from seeds of tomato varieties}

\begin{tabular}{|l|l|l|l|l|l|}
\hline \multirow{2}{*}{ Test cultures } & \multicolumn{5}{|l|}{ Diameter of the zone of absence of growth, mm } \\
\cline { 2 - 7 } & CHA3 & OB1 & OB2 & KM2 & FL1 \\
\hline $\begin{array}{l}\text { C. michiganensis subsp. } \\
\text { michiganensis P8 }\end{array}$ & 80 & 40 & 70 & 50 & 60 \\
\hline $\begin{array}{l}\text { C. michiganensis subsp. } \\
\text { michiganensis P12 }\end{array}$ & 40 & 40 & 44 & 30 & 70 \\
\hline C. michiganensis subsp. & 50 & 44 & 44 & 20 & 30 \\
\hline
\end{tabular}




\begin{tabular}{|l|l|l|l|l|l|}
\hline michiganensis P73 & & & & & \\
\hline $\begin{array}{l}\text { C. michiganensis subsp. } \\
\text { michiganensis P110 }\end{array}$ & 50 & 40 & 44 & 30 & 60 \\
\hline $\begin{array}{l}\text { C. michiganensis subsp. } \\
\text { michiganensis P115 }\end{array}$ & 44 & 80 & 50 & 30 & 40 \\
\hline $\begin{array}{l}\text { C. michiganensis subsp. } \\
\text { michiganensis 4999 }\end{array}$ & 80 & 80 & 60 & 44 & 30 \\
\hline P. syringae pv. tomato 4213 & 60 & 60 & 74 & 20 & 20 \\
\hline P. syringae pv. tomato Pst2 & 50 & 34 & 80 & 44 & 26 \\
\hline P. syringae pv. tomato Psr120 & 50 & 50 & 80 & 46 & 20 \\
\hline P. syringae pv. tomato BB9 & 60 & 30 & 76 & 40 & 60 \\
\hline$X$. vesicatoria 9098 & 56 & 50 & 74 & 44 & 40 \\
\hline NIR 05 & 2,29 & 2,09 & 1,92 & 2,29 & 1,92 \\
\hline
\end{tabular}

The lower antagonist sensitivity was noted by strains $C$. michiganensis subsp. michiganensis $\mathrm{P} 8, \mathrm{P} 12$, P73, P110, P115 and 4999 (a bacterial cancer agent), whose growth inhibition zones ranged from 44 to $70 \mathrm{~mm}$. The diameter of the growth inhibition of $C$. michiganensis subsp. michiganensis P8, P12, P73, $\mathrm{P} 110, \mathrm{P} 115$ and 4999 isolate OB1 was $40-80 \mathrm{~mm}$. In relation to strains $P$. syringae pv. tomato 4213 , Pst2, Psr120 and BB9 isolates OB1 resulted in the formation of growth inhibition zones within the range of $30-60 \mathrm{~mm}$. Isolate $\mathrm{CHA} 3$ also had a high antagonistic activity against bacterial pathogens and bacterial droplets. Level of antagonistic activity to strains $C$. michiganensis subsp. michiganensis $\mathrm{P} 8$, $\mathrm{P} 12, \mathrm{P} 73, \mathrm{P} 110, \mathrm{P} 115$ and 4999 was in the range of 40 to $80 \mathrm{~mm}$. To strains $P$. syringae pv. tomato 4213, Pst2, Psr120 and BB9 isolate CHA3 exhibited less antagonistic activity, while growth inhibition zones ranged from 50 to $60 \mathrm{~mm}$. Isolates KM2 and FL1 have a slightly lower antagonistic activity in relation to test cultures. The diameter of the growth inhibition of $C$. michiganensis subsp. michiganensis $\mathrm{P} 8, \mathrm{P} 12, \mathrm{P} 73, \mathrm{P} 110, \mathrm{P} 115$ and 4999 isolates of $\mathrm{KM} 2$ was $20-50 \mathrm{~mm}$, strains $P$. syringae pv. tomato 4213, Pst2, Psr120 and BB9 - $20-46 \mathrm{~mm}$. Level of antagonistic activity of isolate FL1 to strains C. michiganensis subsp. michiganensis $\mathrm{P} 8, \mathrm{P} 12, \mathrm{P} 73, \mathrm{P} 110, \mathrm{P} 115$ and 4999 was in the range of 30 to 70 $\mathrm{mm}$, and P. syringae pv. tomato 4213, Pst2, Psr120 and BB9 $-20-60 \mathrm{~mm}$. The isolates exhibited antagonistic activity also to the bacterium pathogen, the diameter of the inhibition of the growth of strain $X$. vesicatoria 9098 was $40-74 \mathrm{~mm}$.

Thus, our research has shown that isolates $\mathrm{CHA} 3, \mathrm{OB} 1, \mathrm{OB} 2, \mathrm{KM} 2$ and FL1 with different activity are able to suppress the growth of test cultures and are potential strains for controlling bacterial cancer agents, bacterial drooping and black bacterial spotting.

\section{Conclusions}

The microbiota of tomato roots not fungicide seed is more diverse than protruded. Most often, unprocessed seeds of tomato varieties isolated isolates that form colonies of yellow-hot color and were previously identified as Pantoea agglomerans. The identified isolates of yellow-pigmented bacteria are the main microorganisms for the protection of tomato varieties of Ukrainian selection from pathogens. The cultivation of seeds of tomato varieties resulted in the disappearance of microorganisms with antagonistic activity against phytopathogenic bacteria. Isolates of OB1, O2, O3, KM2 and FL1 from epiphytic microflora of non-fungicidal seeds of tomato plants are promising to limit the development of bacterial cancers, bacterial droopiness and black bacterial spotting. Growth inhibition zones due to isolates in relation to C. michiganensis subsp. michiganensis, make up 40 to $80 \mathrm{~mm}, P$. syringae pv. tomato - $30-$ 80 and $X$. vesicatoria $-40-74 \mathrm{~mm}$.

\section{Bibliography}

1. Antagonisticheskie svoystva novykh shtammov mikroorganizmov, vydelennykh iz pochv Moldovy / S. A. Burtseva, T. F. Syrbu, V.A. Slanina, S.A. Tolochkina, S.N. Kodryanu // Mikrobiolohiia i biotekhnolohiia. - 2007. - №1. - S. $40-45$.

2. Bakterialni khvoroby silskohospodarskykh roslyn i pestytsydy / Petrychenko V. F., Korniichuk O.V., Pasichnyk L.A., Butsenko L.M. ta in. // Visnyk ahrarnoi nauky. - 2013. - № 4. - S. 21-26. 
3. Gvozdyak R. I. Pantoea agglomerans - vozbuditel' bolezney pyreya polzuchego (Elytrigia repens) i raygrasa vysokogo (Arrhenatherun elatius) / R. I. Gvozdyak, L. M. Yakovleva // Mikrobiolohichnyi zhurnal. -2007 . -69 , № 1. - S. $61-67$.

4. Diahnostyka fitopatohennykh bakterii. Metodychni rekomendatsii / V. P. Patyka, L. A. Pasichnyk, L. A. Dankevych, S. M. Moroz ta in. - Kyiv, 2014. - 76 s.

5. Ellanska N. E. Ekoloho-trofichni vzaiemovidnosyny vyshchykh roslyn i mikroorhanizmiv / N. E. Ellanska, E. A. Holovko // Fiziologiya i biokhimiya kul't. rasteniy. - 2004. - 36, № 5. - S. 383-389.

6. Epifitna mikroflora soi $v$ umovakh Lisostepu Ukrainy / I. I. Koshevskyi, N. V. Zhytkevych, V. S. Mytko // Naukovyi visnyk Uzhhorodskoho natsionalnoho universytetu. Seriia: biolohiia. - 2001. - Vyp. 9. S. $114-115$.

7. Kanivets V. I. Bakterial'naya mikroflora protravlennykh semyan sakharnoy svekly / V. I. Kanivets, I. N. Pishchur // Mikrobiologiya. - 2001. - 70, № 3. - S. 370 - 373.

8. Mikrobiota lystkiv i zerna yachmeniu yaroho za dii herbitsydu i biopreparatu / V. P. Karpenko, V. Ya. Bilonozhko, R. M. Prytuliak, S. P. Poltoretskyi, I. I. Mostoviak // Problemy ekolohichnoi biotekhnolohii. 2012. - № 2. - S. 42-53.

9. Osnovy ucheniya ob antibiotikakh: Uchebnik. 6-e izd., pererab. i dop. / N.S. Egorov. - M.: Izd-vo MGU; Nauka 2004. - $528 \mathrm{~s}$.

10. Pasichnyk L. A. Epifitna i endofitna mikroflora zdorovoho zerna ta vehetuiuchykh roslyn pshenytsi / L. A. Pasichnyk, R. I. Hvozdiak, S. F. Khodos // Visnyk DAU, seriia Biolohiia. - 2005. - № 2 (15). - S. 141 $-148$.

11. Pasichnyk L. A. Epifitna i endofitna mikroflora zdorovoho zerna ta vehetuiuchykh roslyn pshenytsi // Fitopatohenni bakterii. Fitontsydolohiia. Alelopatiia: zb. statei / L. A. Pasichnyk, R. I. Hvozdiak, S. F. Khodos - Zhytomyr: DAU, 2005. - S. 8 - 13.

12. Pasichnyk L. A. Epifitna faza isnuvannia Pseudomonas syringae pv. coronafaciens - zbudnyka oreolnoho bakteriozu vivsa / L. A. Pasichnyk // Mikrobiolohichnyi zhurnal. - 1999. - 61, № 6. - S. 9-14.

13. Serhiienko V. Vplyv obrobky nasinnia na rozvytok roslyn ta produktyvnist soi / V. Serhiienko // Ahrobiznes sohodni. - 2014. - № 15-16. - S. 286-287.

14. Klement Z. Methods in phytobacteriology / Z. Klement, K. Rudolph, D. C. Sands - Budapest, 1990. $-567 \mathrm{p}$. 